\title{
Analysis of the Effect of Profitability, Company Growth, and Liquidity on Capital Structure: A Case Study of Indonesia
}

\author{
Setia Budi Kurniawan, and Mira Aisyah Nendya \\ University of Merdeka Malang, Indonesia
}

\begin{abstract}
:
Capital structure is a balance or comparison between foreign capital and own capital. The optimal capital structure is the capital structure that optimizes the balance between risk and returns so as to maximize the share price. For this reason, in determining the capital structure of a company, it is necessary to consider various variables that influence it. The purpose of this study was to determine the effect of independent variables consisting of profitability, company growth, and liquidity on the dependent variable of capital structure in cigarette companies listed on the Stock Exchange. The type of research used is explanatory research by looks for the relationship between the variables studied through hypothesis testing. The population in this study were all cigarette companies listed on the Indonesia Stock Exchange in 2013-2020 using the purposive sampling method and the analysis method used was multiple regression analysis. The results of this study indicate that profitability and liquidity have no effect on capital structure. The company's growth has a significant effect on the capital structure. Profitability, company growth, and liquidity simultaneously affect the capital structure.
\end{abstract}

Keywords: Company Growth, Capital Structure, Liquidity, Profitability.

\section{INTRODUCTION}

The increasingly high economic growth in Indonesia has led to high business competition between one company and another. This competition requires companies to be able to increase their value and prosper their shareholders. The company must increase its value from the various activities carried out, one of which is the right funding decision for the company. The decision is one of the decisions taken by the manager to optimize the achievement of company performance (Hapsari, 2017).

Funding decisions are decisions about how to use debt compared to equity in financing investments. For many companies, funding sources that only come from capital are often felt to be lacking. The capital that can be used by the company can come from within the company (internal) or from outside (external) parties. Every company, of course, needs capital to finance operational activities and for the benefit of developing its business.

Capital is an important element for every company, because the greater the capital owned by the company, the greater the operational activities that can be carried out. The funds available in the capital structure will be used to fund the company's investment in various types of available investments, from making these investments, the company will create value, then the capital structure will determine the extent to which, how, value is created which will be reflected in profits and prices. company shares (Pratiwi 2014).

According to Brigham and Houston (2011: 153) making decisions about the right source of funding consisting of debt and own capital is important because it relates to the survival of companies that are developing and require capital from debt and equity. According to Putri (2012), too much debt will also hamper the development of the company, this can make investors also think twice about investing their capital so that it becomes one of the problems that arise from determining the capital structure that is not optimal. Optimal capital structure is one of the factors that have competitiveness in the long term.

The capital structure in this study is represented by Debt to Equity (DER) and Debt to Asset Ratio (DAR). The capital structure has a relationship with the company's stock price, because one of the elements that make up the stock price is the investor's perception of the company's performance and the capital structure is one of the elements that determine the good or bad performance of the company. The amount of risk borne by the winner and the expected rate of return or rate of profit are directly influenced by capital structure decisions (Brigham and Hoston, 2001). Capital structure decisions taken by managers not only affect the company's profitability, but also affect the financial risks faced. company, such as the possibility of the company to pay its obligations and the possibility of profits that cannot be achieved according to the company's targets. Based on this explanation, it appears that capital is an important decision for the survival of the company on the capital structure. 
Funding or meeting funding needs must be carried out properly and efficiently. Fulfillment of funds can come from internal sources, funding originating from internal sources is formed from within the company itself. Another source of funds is the source of funds obtained from outside the company itself such as funds from debt and the issuance of shares called external sources of funds. Determining which sources to use is considered important because each of these sources of funds has a different cost of capital, this makes financial managers able to determine the most appropriate alternative choice of funding sources. In this case the company must consider where the source of the funds, whether from debt, shares, or a combination of both. Many factors influence the decision of a manager in determining the company's capital structure. Capital structure can be influenced by fixed assets, profitability, risk, company size, liquidity, taxes, and growth. (Habibah 2015)

This study uses manufacturing companies engaged in the cigarette industry which are listed on the Indonesia Stock Exchange (IDX). The reason for researching this company is because this stock is the most resistant to economic crisis when compared to other sectors, because this company is able to face pressures from government regulations. This company is still profitable to absorb labor and has a large market share and also has a large tax for the state, like it or not, the company must continue to survive even though it is prohibited. Although some of the products are not basic necessities, usually each household has a supply of manufactured products according to the habits of each household, so it is possible for people to consume the products produced by this company. Another reason is that the high use of cigarette products makes people's purchasing power high as well. Many companies want to enter the sector, the competition will increase drastically, so the company must strengthen its internal factors in order to survive in the competition. One way to keep the company afloat is to manage its capital structure well, and the company must consider the variables that can affect the company's capital structure. Several previous studies by Naibaho (2015) resulted in profitability research having a positive effect on capital structure, Meanwhile, according to Less y (2016), profitability research has a negative effect on capital structure and according to Rofiqoh \& Kurnia (2014) says there is no effect on capital structure. While regarding the growth of the company Pratiwi (2014) produced research on the existence of a positive relationship between company growth and capital structure, Widayanti (2016) said that there was no significant relationship between company growth and capital structure. Some researchers also say differently about the relationship between liquidity and capital structure, according to Hapsari (2013), that liquidity research has a positive effect on capital structure, and according to Rofiqoh and Kurnia (2014), liquidity research has a negative effect on capital structure.

Based on the problems above, this study has the following objectives to examine and analyze the effect of profitability on the capital structure of cigarette companies in Indonesia, to test and analyze the effect of liquidity on the capital structure of cigarette companies in Indonesia, and to examine and analyze the effect of company growth on the structure of the company. capital in cigarette companies in Indonesia.

\section{LITERATURE REVIEW}

\subsection{Capital Structure}

Capital is a right owned by the company. Capital has several components consisting of paid-in capital, share premium, retained earnings, profit reserves and others (Kasmir, 2010:81). According to Mulyono (2002:227), capital is the amount of funds invested into a company by its owners to form a business entity and in its development capital can be reduced if there is a loss and can grow when there is a profit. From these two opinions, it can be concluded that capital is funds owned by the company which can come from its own funds or from outside and can be used by the company to finance all company activities.

Capital structure has various definitions, many sources state the definition of capital structure, including capital structure is permanent financing consisting of long-term debt, own capital and preferred stock according to Copelan \& Weston (2003:3). Meanwhile, according to (Syamsuddin, 2004:9) "Capital structure is a comparison of long-term debt with own capital".

From the opinion above, it can be concluded that in compiling sources of capital to finance the activities of a company, it is necessary to be based on a balance between long-term debt and own capital, the company must also be responsible for taking the risk and if it has a specific purpose in using the funds.

There are many factors that affect the capital structure of a company. The following will describe some opinions about the factors that affect the capital structure. The variables that affect the capital structure (Seftiani, 2011) are the level of sales, companies with sales of a company with relatively stable sales have a stable cash flow as well, so they can use larger debt than companies with unstable sales, for example, companies which is engaged in agribusiness, where the price of the product is uncertain and fluctuates, the cash flow becomes unstable. Therefore, it should not be financed with large debts. Asset structure, a company that has a fixed asset structure in large quantities can use large amounts of debt, because of the scale of large companies it will be easier to get access to sources of funds than small companies. This is due to fixed assets that can be used as collateral for the company's debt, but large amounts of debt will increase the risk to the company such as business risk and also financial risk to the company. The company's growth rate as measured by changes in the company's total sales. Sales growth shows that the company's growth is one measure in assessing the company's ability to increase its sales from year to year and in this case can provide convenience for companies to obtain external funding. Profitability, profitability of the previous period is an important 
factor in determining the capital structure, with large retained earnings, companies will prefer to use retained earnings before using debt.

\subsection{Profitability}

Profitability is the company's ability to earn profits in relation to sales, total assets and own capital (Sartono, 2004:248). Companies with higher profitability have a lower need for access to credit markets, because companies tend to use their internal funds (retained earnings). Research conducted (Qien et al, 2007) shows that profitability has an effect on the company's capital structure. The higher the profit, the lower the need for external funds (debt).

\subsection{Company Growth Rate}

The growth of a company can be seen from how far the company will use debt as a source of financing. Companies with high growth rates should use equity as a source of financing to avoid agency costs oragency cost) between shareholders and company management, on the other hand, companies with low growth rates should use debt as a source of financing because the use of debt will require the company to pay interest regularly.

Companies with a larger size are seen as more capable of dealing with crises in running their business. Larger companies tend to disclose more information to outside investors than smaller companies. Larger companies can easily obtain external loans or funds. So that the larger the size of the company, the tendency to use debt is greater to meet capital needs than small companies. Company size is often used as an indicator for the possibility of bankruptcy for a company.

The company's ability to survive in competitive conditions is shown by its sales growth. Higher sales growth compared to cost increases will result in an increase in company profits. Meanwhile, a company with a negative growth ratio has the poten tial to experience a decline in profit so that if management does not take corrective action, it is possible that the company will not be able to maintain its viability.

The above-average growth rate can be achieved by the company by increasing the market share of the overall industry demand. Calculating sales growth can be done by calculating the compound year's sales growth rate while studying long-term trends in sales and other variables. Increasing market share must be in line with the right marketing strategy and the company is always innovating, this means that with the right strategy it can increase sales growth through developing products that are of interest to consumers.

\subsection{Liquidity}

According to Sutrisno (2012:14) the company's ability to fulfill its obligations that must be fulfilled immediately is called liquidity. Companies with high liquidity have large internal funds, so the company will first to finance its investment before using external financing through debt. The higher the liquidity the more trust short-term creditors to finance the company.

Funding requirements for current assets are principally financed by short-term liabilities. The ability to pay for short-term obligations is very dependent on the means of payment owned by the company, the size of the means of payment owned by the company is referred to as the paying power or paying power of a company which will make the company have the ability to pay its short-term obligations.

\subsection{Research Hypothesis}

Based on the theory derived from previous researchers, the following hypotheses can be determined:

1) Brigham and Houston (2011: 189) hypothesize that companies with high profits generally use relatively little debt because with these high profits, companies can use capital only with retained earnings. Profitability is a measure of the success of a company. In general, the company aims to make a profit (profit) and this profit is one indicator of the success or failure of a company. From several previous studies, it can be seen that according to Naibaho (2015), Pratiwi (2014), Hapsari (2016), Mikrawardhana (2015), Shubita \& Alsawalhah (2012), and Negasa (2016) resulted in profitability research having a positive and significant effect on capital structure, and according to Lessy (2016), Bhawa \& Dewi (2015), Riasita (2014), and Mohammadzadeha (2013) resulted in profitability research having a negative effect on capital structure, whereas according to Rofiqoh \& Kurnia (2014), Kurniawan (2013), Widayanti (2016), Bhattarai (2016) resulted in research that has no effect of profitability on capital structure. From some of the statements above, there are still inconsistencies in the results, so the following hypotheses are generated:

H1: Profitability has an effect on capital structure.

2) Company size is how small a company's assets are. Bambang Riyanto (2001: 279) states that the size of a company also affects the company's capital structure. The size of the company can affect the capital structure because the larger a company will tend 
to use greater debt. Because one of the advantages possessed by large companies is that they tend to be more trusted by creditors because they are considered to have a smaller risk compared to companies that have small company sizes.

From several previous studies, it can be seen that according to Pratiwi (2014) produced research that there is a positive relationship between company growth and capital structure, while according to Kurniawan (2013) and Widayanti (2016) there is no significant relationship between company growth and capital structure. From some of the statements above, there are still inconsistencies in the results, so a hypothesis is generated

$\mathrm{H} 2$ : The growth of the company has an effect on the capital structure.

3) Companies that are able to meet their long-term obligations have a good capital structure. Companies that have a positive relationship between liquidity and capital structure will encourage investors to provide large debt because investors feel guaranteed by the value of liquid company assets.

From several previous studies, it can be seen that according to Hapsari (2013), Bhawa \& Dewi (2015), Mikrawardhana (2015), Ghazemi \& Razak (2016), liquidity research has a positive effect on capital structure, and according to Rofiqoh and Kurnia (2014), Lessy (2016), Riasita (2014), Kurniawan (2015), and Widayanti (2016) produced research that liquidity had a negative effect on capital structure, while according to Bhattarai (2016) said that liquidity had no effect on capital structure. From some of the statements above, there are still inconsistencies in the results, so a hypothesis is generated

H3 : Liquidity affects the capital structure.

4) From several statements by experts and some previous researchers above, the authors conclude that the three variables above which consist of profitability, company growth, and liquidity have an influence and some have no effect on capital structure. From the statement above, there are still inconsistencies in the results, so the following hypotheses are generated:

H4 : Profitability, company growth, liquidity affect the capital structure.

\section{RESEARCH METHODS}

\subsection{Variable Operational Definition}

The operational definitions of the variables used in this study are as follows:

1) Capital Structure (Y) Capital structure is calculated by comparing (ratio) between total debt to total equity and total assets.

2) Profitability (X1)

Profitability is seen from the company's ability to obtain prices.

3) Company Growth (X2)

The growth of the company in this study uses the proxy of sales growth.

4) Liquidity (X3)

Liquidity is a measure of the ability of the company's short-term debt by looking at the company's current assets relative to current debt.

\subsection{Population and Sampling Techniques}

The population of this study are companies listed on the Indonesia Stock Exchange for the period 2013 - 2020 . The sample collection technique uses a purposive sampling technique. The criteria for the research sample are:

1) The companies studied are cigarette companies listed on the Indonesia Stock Exchange in $2013-2020$

2) The company issued financial statements as of December 31 for the period $2013-2020$.

3) The companies studied were not delisted in $2013-2020$.

4) The company has complete data needed in the study including having long-term debt in the research period 2013 - 2020.

\subsection{Data analysis technique}

In this study, the data analysis techniques used for the steps of calculating financial statements include: Research on the effect of company growth, profitability on capital structure (the case of companies listed on the Indonesia Stock Exchange between 2013-2020) using the linear regression analysis method (Multiplier Regression Method) using pooled data. The formulation of the model is as follows:

$$
Y=\beta_{0}+\beta_{1} X_{1}+\beta_{2} X_{2}+\beta_{3} X_{3}+\varepsilon
$$

Description :

$\mathrm{Y} \quad=$ Capital Structure 
$\beta_{0}=$ constant

$\beta_{1}-\beta_{3}=$ Beta coefficient of independent variable

$\mathrm{X}_{1}=$ Profitability

$\mathrm{X}_{2}=$ Company Growth

$\mathrm{X}_{3}=$ Liquidity

$\varepsilon=$ Disturbance Error

\section{RESULTS AND DISCUSSION}

\subsection{Research result}

\subsubsection{Multiple Linear Regression Analysis}

Multiple regression analysis was used to determine the magnitude of the influence of the variables profitability, company growth and liquidity on the capital structure (Y). The results of these calculations can be seen in the table below:

Table 1 Recapitulation of Multiple Linear Regression Analysis Results

\begin{tabular}{|l|c|c|c|}
\hline \multicolumn{1}{|c|}{ Variable } & Regression Coefficient & tcount & Sig. \\
\hline Profitability & 0.756 & 0.478 & 0.636 \\
Company growth & 4.143 & 5.503 & 0.000 \\
Liquidity & -0.298 & -1.184 & 0.246 \\
\hline constant & 0.472 & \\
R & 0.762 & \\
Adjuted R Square & 0.535 & \\
Fcount & 12,902 & \\
Sig & 0.000 & \\
N & 32 & \\
\hline Dependent variable = Capital structure (Y) & \\
\hline
\end{tabular}

Source: Data processed.

The results of the multiple regression calculation can be seen in the following formulation:

$\mathrm{Y}=0.472+0.756 \mathrm{X} 1+4.143 \mathrm{X} 2-0.298 \mathrm{X} 3$

Based on the results of these equations, it can be explained as follows:

a. The constant (a) $=0.472$ indicates the size of the capital structure (Y), if there is no influence of profitability, company growth, and liquidity then the capital structure is 0.472 .

b. The regression coefficient X1 (Profitability) is 0.756 (b1), indicating the magnitude of the effect of X1 (Profitability) on the capital structure, the regression coefficient is positive indicating X1 (Profitability) has a unidirectional effect on the capital structure (Y), which means an increase in profitability there is a tendency to increase the capital structure, and vice versa.

c. The regression coefficient of X2 (company growth) is 4.143 (b2), indicating the magnitude of the effect of X2 (company growth) on the capital structure (Y), the regression coefficient is positive indicating X2 (company growth) has a unidirectional effect on the capital structure (Y), which means every an increase in the company's growth variable there is a tendency to increase the capital structure, and vice versa.

d. The regression coefficient X3 (liquidity) is -0.298 (b3), indicating the magnitude of the effect of X2 (liquidity) on the capital structure (Y), the regression coefficient is negative indicating that X3 (liquidity) has an opposite effect on the capital structure $(\mathrm{Y})$, which means every increase In the liquidity variable, there is a tendency for the capital structure to decrease, and vice versa.

Multiple correlation coefficient $(\mathrm{R})$ is 0.762 ; shows that together there is a strong and unidirectional relationship between profitability, company growth and liquidity with a capital structure $(\mathrm{Y})$ of $76.2 \%$. This relationship can be categorized as strong, as it is known that a relationship is said to be perfect if the correlation coefficient reaches $100 \%$ or 1 (either with positive or negative numbers).

The value of the coefficient of determination (adjusted $\mathrm{R}$ square) is 0.535 . This figure shows that the variables of profitability, company growth, and liquidity are able to contribute to the dependent variable (capital structure) by $60.7 \%$, while the remaining $39.3 \%$ is caused by other variables outside the research variables. 


\subsubsection{Hypothesis Test}

a. First Hypothesis Testing

The first hypothesis testing using $t$ test. The results of the $t$ test obtained a t value of 0.478 with a significance value of $0.478>$ 0.05 so Ho is accepted or Ha is rejected, so it is not proven that the X1 variable (profitability) has an effect on the capital structure (Y). Thus the first hypothesis is not statistically tested.

b. Second Hypothesis Testing

Testing the second hypothesis by using the $t$ test. The results of the t test obtained a $t$ value of 5.503 with a significance value of $0.000<0.05$ so Ho is rejected or Ha is accepted, so that the X2 variable (company growth) has a significant effect on the capital structure (Y). Thus the second hypothesis is statistically tested.

c. Third Hypothesis Testing

Testing the third hypothesis by using the $t$ test. The results of the $t$ test obtained a $t$ value of -1.184 with a significance value of $0.246<0.05$ so Ho is accepted or Ha is rejected, so that the X3 variable (liquidity) has a significant effect on the capital structure (Y). Thus the third hypothesis is statistically tested.

d. Fourth Hypothesis Testing

The calculation results obtained an $\mathrm{F}$ value of 12,902 , with a probability value of 0.000 less than $\alpha=0.05(0.000<0.05)$, then Ho is rejected and $\mathrm{Ha}$ is accepted, which means that the independent variables: profitability, company growth, and liquidity simultaneously or jointly have a significant effect on capital structure. Thus the fourth hypothesis is statistically tested.

\subsection{Discussion}

Discussion of the analysis of the effect of profitability, company growth, and liquidity on the capital structure.

1) Based on the calculation results, profitability has a significance level of 0.636 (not significant at 0.05 ) so it can be concluded that profitability has no significant effect on capital structure.. This finding is in accordance with that presented by Kurniawan (2013) and Riasita (2014) Widayanti et al. (2016) which results in research that profitability does not have a significant effect on capital structure. This is why the company does not consider profitability as a factor influencing the decision to determine long-term funding. The fixed capital structure increases when the level of profitability fluctuates, meaning that profitability does not affect the capital structure decisions of cigarette companies listed on the IDX for the 2013-2020 period. The results of this study are not in accordance with research conducted by Naibaho, et al (2015), Pratiwi (2014), hapsari (2016), lessy (2016), Bhawa \& Dewi (2015), Mikrawardhana et al. (2015), Tariku Negasa (2016) which states that there is a significant influence between profitability and capital structure. Thus $\mathrm{H} 1$ is rejected.

2) Based on the calculation results, the company's growth has a significance level of 0.000 (significant at 0.05 ) so it can be concluded that the company's growth has a significant effect on the capital structure.Companies with high growth rates should use equity as a source of financing to avoid agency costs oragency cost) between shareholders and company management, on the other hand, companies with low growth rates should use debt as a source of financing because the use of debt will require the company to pay interest regularly. As the opinion (Seftiani, 2011) which states that one of the factors that affect the capital structure is the growth of the company. This finding is in accordance with that conveyed by Pratiwi (2014) which resulted in research that there is a significant influence between company growth and capital structure. This causes that as a company develops, it will increase sales and make the capital structure more optimal and does not require debt or external funds that are large enough to meet the needs of its capital structure to be optimal. The results of this study are not in accordance with research conducted by Kurniawan (2013) and Widayanti (2016) which states that there is no significant effect between company growth and capital structure. Thus $\mathrm{H} 2$ is accepted.

3) Based on the calculation results, liquidity has a significance level of 0.246 (not significant at 0.05 ) so it can be concluded that liquidity has no significant effect on capital structure.. This finding is in accordance with what was conveyed by Bhattarai (2016) which resulted in research that there is no significant influence between liquidity on capital structure. abundant, so companies are more likely to use internal funds first to finance their investments before using external financing through debt. The results of this study are not in accordance with research conducted by Hapsari (2013), Bhawa \& Dewi (2015), Mikrawardhana (2015), Ghazemi \& Razak (2016), Rofiqoh and Kurnia (2014), Lessy (2016), Riasita (2014), Kurniawan (2015), and Widayanti (2016) which resulted in liquidity research having a significant effect on capital structure. Thus H3 is rejected.

4) Based on the results of the calculation of profitability, company growth and liquidity have a significance level of 0.000 (significant at 0.05 ) so it can be concluded that profitability, company growth and liquidity have a joint effect on capital structure. Companies that have a high rate of return on the assets they manage illustrate the company's ability to generate high profits. The stable level of profitability of the company is one of the important things that managers must pay attention to in choosing a capital structure. The more stable the profitability means the smaller the company's loans. Companies with high 
growth rates require larger funds to finance their capital. Internal funding sources may be insufficient, therefore the company also needs external funds to be able to help the company's operations. Through a high level of sales growth shows the company's ability to generate stable profits. The increase in the company's sales growth will have an effect on increasing the capital structure, for companies with high growth rates, the tendency to use debt is greater than companies with low growth rates. The higher the company's liquidity, the better the company's ability to meet its short-term obligations. The increase in the company's sales growth will have an effect on increasing the capital structure, for companies with high growth rates, the tendency to use debt is greater than companies with low growth rates. The higher the company's liquidity, the better the company's ability to meet its short-term obligations. The increase in the company's sales growth will have an effect on increasing the capital structure, for companies with high growth rates, the tendency to use debt is greater than companies with low growth rates. The higher the company's liquidity, the better the company's ability to meet its short-term obligations.

\section{CONCLUSIONS AND SUGGESTIONS}

\subsection{Conclusion}

This study aims to examine the effect of profitability, company growth and liquidity on the capital structure of cigarette companies listed on the IDX and to analyze the variables that have a dominant influence on the capital structure of cigarette companies listed on the IDX. Based on the results of hypothesis testing in this study, it can be concluded several things, namely: Profitability has no significant effect on the capital structure of cigarette companies on the IDX for the 2013-2020 period. The company's growth has a significant effect on the capital structure of cigarette companies on the IDX for the 2013-2020 period. Liquidity has no significant effect on the capital structure of cigarette companies on the IDX for the 2013-2020 period.

\subsection{Suggestion}

For further researchers, the suggestion that researchers can convey to future researchers is to add factors that affect the capital structure, so that it can complement the results of previous studies. Increasing the scope of the research population is not only cigarette companies but also other sectors that are rarely studied. Extend the research observation period, so that the results obtained are more representative of the existing theory.

Suggestions for investors, the capital structure generated by the researchers refers to the company's growth can affect the capital structure. Therefore, it is recommended that investors invest in the cigarette industry because in the coming period there will be many cigarette industries and will focus on the growth of companies with high profit margins.

In investing in the company, must consider the capital structure and profitability that can be obtained by the company. If the capital structure is high and the expected profitability is lower than the interest rate, then investors are more appropriate to invest in other industries because the profits are greater.

Suggestions for the company, in carrying out the company's operational activities, the company's management should be right in choosing alternative funding so that the company can increase its ability to generate operating profit from its own capital.

\section{REFERENCES}

Bhattarai Y Raj. 2016. The Effect Of Liquidity On The Capital Structure Of Nepalese Manufacturing Companies. International Journal of Marketing \& Financial Management. Journal Vol 4, Issue 3.

Bhawa Ida Bagus M.D. and Made Rusmala D.S. 2015. The Influence of Company Size, Liquidity, Profitability, and Business Risk on the Capital Structure of Pharmaceutical Companies. Journal of Management Unud. Vol 4. No. 7.

Brigham \& Houston. 2011. Fundamentals of Financial Management. Edition ten. Jakarta: Salemba Empat.

Brigham, E.F. and Houston, F. Joel. 2001. Financial Management, Edition 8, Indonesian Edition. Jakarta: Salemba Empat.

Habibah, Maulia. 2015. Analysis of the Effect of Profitability, Asset Structure, Liquidity, and Sales Growth on Capital Structure. Journal of Accounting Science and Research, Vol. 4 No. 7.

Kamir. 2010. Introduction to Financial Management. Jakarta: Kencana.

Kurniawan G. Dwi. 2013. Effect of Liquidity, Company Size, Sales Growth, and Profitability on Capital Structure. Essay. Yogyakarta State University.

Lessy D. Anggriyani. 2016. The Effect of Firm Size, Liquidity, Profitability, and Asset Structure on Capital Structure in Manufacturing Companies. Essay. Yogyakarta State University.

Mikrawardhana M Riga, Raden. R. H and Devi F. A. 2015. Effect of Profitability and Liquidity on Capital Structure. Journal of Business Administration (JAB), Vol. 28 No. 2.

Mohammadzadeh Mehdi et al. 2013. The Effect of Capital Structure on the Profitability of Pharmaceutical Companies The Case of Iran. Iranian Journal of Pharmaceutical Research. Journal of Vol. 12. No. 3.

Mulyono. 2002. Financial Management. Andi Offset. Yogyakarta.

Negasa Tariku. 2016. The Effect of Capital Structure on Firms' Profitability. (Evidenced from Ethiopian). Preprints (www.preprints.org). doi:10.20944/preprints201607.0013.v1. 
Pratiwi. L. Nunung. 2014. The Effect of Profitability and Company Growth on Capital Structure. Essay. Independent University. Poor.

Riasita Defia. 2014. The Effect of Profitability, Liquidity, Asset Growth, Asset Structure and Company Size on Capital Structure in Manufacturing Companies. Essay. Yogyakarta State University.

Riyanto, Bambang. 2001. Fundamentals of Corporate Expenditure, Fourth Edition, Seventh Printing, BPFE. Yogyakarta.

Rofiqoh, N and Kurnia. 2014. The Effect of Asset Structure, Liquidity, and Profitability on the Company's Capital Structure. Journal of Accounting Science and Research, Vol. 2 No. 1.

Sartono, Agus. 2004. Financial Management, Theory and Applications, Third Edition, BPFE. Yogyakarta. 